\title{
REMOVAL OF AS(III) WITH (CYNODON DACTYLON) GREEN DUB AND ORANGE PEEL FROM AQUEOUS MEDIUM
}

\author{
Kiran Kumari $^{1}$, Ashok Kumar Jha ${ }^{1, \bowtie}$, Pranita $^{2}$, Anjana Kumari ${ }^{1}$ \\ and Usha Sharma ${ }^{3}$ \\ ${ }^{1}$ Research Scholar, University Department of Chemistry, T.M.B.U., \\ Bhagalpur-812007(Bihar) India \\ ${ }^{2}$ P.G. Department of Chemistry, V.B University, Hazaribagh-825302(Jharkhand)India \\ ${ }^{3}$ Department of Chemistry, G.B College, Naugachia, T.M. Bhagalpur University, \\ Bhagalpur- 853204(Bihar) India, \\ Corresponding Author: ashokjha39@gmail.com
}

\begin{abstract}
In the present study,Cynodondactylon(green dub) and orange peel powder have been utilized for remediation of As(III) ion from an aqueous medium. Different weights of Cynodondactylon have been treated with 2ppm As(III) solution up to a fixed time interval and again fixed weight of Cynodondactylon has been treated up to different intervals of time at a $\mathrm{pH}$ range of 2-6.5. Similar experiments have been repeated with orange peel powder at different $\mathrm{pH}$ values to know the adsorption isotherm, remediation efficiency, and adsorption rate. Results show that percentage removal in 30 minutes is $99.5 \%$ and agitation time for equilibrium is 30 minutes, with orange peel powder whereas maximum percentage removal with Cynodondactylon is $98.5 \%$ at $\mathrm{pH} 2$. Thus orange peel and Cynodondactylon both could be used as a potential adsorbent for removal As(III) from an aqueous medium.
\end{abstract}

Keywords: Adsorption, Orange Peel, As(III), Remediation, CynodonDactylon.

RASĀYAN J. Chem., Vol. 14, No.2, 2021

\section{INTRODUCTION}

Arsenic contamination in groundwater samples of the Gangetic plain has been reported in India in general and in Bhagalpur district in particular causing a detrimental effect to the health of the inhabitants of the district. ${ }^{1,2}$ When arsenic-contaminated water enters the human body, it attacks the DNA as a result of which various types of cancer takes place. Early symptoms are hyperpigmentation of skin and prolonged use of arsenic-contaminated water may lead to even death..$^{3-6}$ The cause of arsenic-contaminated water may be attributed to the sedimentary rocks which come in contact with the aquifer. ${ }^{7,8}$ Newer Alluvium having grey to black colored argillaceous sediments have emerged as a source of arsenic.

In addition to natural sources, arsenic enters water bodies through anthropogenic sources i.e., metal extraction, anticorrosive agent, steel industries, and industrial effluents. Amongst different oxidation states of $0,+3$, and +5 , Arsenic (III) has been found most common in an aqueous medium. Inorganic arsenic, redox conditions, and $\mathrm{pH}$ values affect the toxicity of arsenic in soils. Humus present in soil has also the capacity to bind with arsenic. Thus arsenic (III) is being released primarily from sediments. Arsenic contaminated groundwater is generally found in newer alluvium from shallow aquifers. ${ }^{9}$ Older alluvium aquifer has rarely arsenic contamination. Arsenic in an aqueous medium can be remediated by some of the methods e.g. adsorption by active charcoal, coagulation, membranes, clay, or clay derivatives. ${ }^{10-12}$ Activated alumina and iron coated sand have also the ability to remove arsenic (III) from an aqueous medium. Soil rich in ferric salts combines with arsenate to give $\mathrm{Fe}$ (III)-arsenate and so it has been established that soil rich in ferric salt has a lesser probability of arsenic contamination. ${ }^{13-15}$

Amongst a series of removal methods, bioremediation may be a better option for selecting appropriate biomass from a wide spectrum of plants, agricultural by-products. Some of the bacterial biomass effective for arsenic removal may be mentioned here as Agrobacterium tumfecians, Bacillus indicus, Bacillus subtilis. ${ }^{16,17}$ but here Cynodondactylon and orange peel have been selected for study keeping in mind the

Rasayan J. Chem., 14(2), 1072-1080(2021)

http://dx.doi.org/10.31788/ RJC.2021.1426178

This work is licensed under a CC BY 4.0 license. 
RASĀYAN J. Chem.

Vol. 14 | No. 2 |1072-1080| April - June | 2021

abundance of Cynodondactylon and orange peel. This method of adsorptive removal has gained an edge over the existing traditional methods e.g. ion exchange, ultrafiltration, liquid-liquid extraction. Due to its low cost and eco-friendly nature, this method has been adopted under suitable laboratory conditions. In most of the traditional methods, it becomes very difficult to mitigate the arsenic concentration below the permissible limit of $0.05 \mathrm{ppm}$. Ion exchange also is not very effective due to the interference of some associated ions. Orange peel contains cellulose, fibers, and protein in its cell wall. Pectin, a carboxylated polysaccharide acts as an intercellular material. Cynodondactylon acts as a phytoremediatior of arsenic. Alkaloids, B-Carotene and Vitamin C are commonly known chemical constituents of Cynodondactylon. Also, docosanoic acid hexadecenoic acid, furfural alcohol, lignin, and flavon are present in Cynodondactylon, a perennial herb widely available with rapid growth. As $\mathrm{pH}$ controls the adsorption of arsenic, the experiment has been carried out at different $\mathrm{pH}$ values. ${ }^{18-20}$

Obtained data of adsorption is explained based on Freundlich and Langmuir adsorption isotherms. Freundlich isotherm represents multilayer adsorption whereas Langmuir adsorption isotherm explains monolayer adsorption. ${ }^{21}$ Freundlich isotherm may be represented as $\mathrm{x} / \mathrm{m}=\mathrm{kc}{ }^{1 / \mathrm{n}}$ where $\mathrm{x} / \mathrm{m}$ is the mass of adsorbate per unit adsorbent and $\mathrm{c}$ is the concentration. ${ }^{22}$ Adsorption kinetics of arsenic may be seen with the Lagergren rate equation given as:

$$
\log \left(\mathrm{q}_{\mathrm{e}}-\mathrm{q}_{\mathrm{t}}\right)=\log \mathrm{q}_{\mathrm{e}}-\mathrm{k} / 2.303 \mathrm{t}
$$

Where, $\mathrm{q}_{\mathrm{e}}$ stands for the amount of arsenic adsorbed at equilibrium and $\mathrm{q}$ at any time $\mathrm{t}$. If the plot of $\log \left(\mathrm{q}_{\mathrm{e}}-\mathrm{q}_{\mathrm{t}}\right)$ vs $\mathrm{t}$ gives the straight line, first-order kinetics is followed. Surface functional groups may be known by conducting FTIR tests before and after adsorption. ${ }^{23}$

\section{EXPERIMENTAL}

Cynodondactylon is collected from the field as this is widespread and abundant. It is washed with deionized water again and again. After repeated washing, the fixed mass of green dub is put in $100 \mathrm{ml}$ $2 \mathrm{ppm}$ sodium arsenite solution up to different intervals of time and different masses of green dub up to fixed time. The kinetics is studied at different time intervals. Another experiment is done with orange peel, a waste after the use of orange. This peel is dried and powdered after repeated washing with double distilled water. This fine powder is mixed with $100 \mathrm{ml} \mathrm{2ppm}$ solution and the residual concentration is known at different intervals of time. Residual concentrations of arsenic are determined from mercoquant arsenic kit and further confirmed by Atomic Absorption Spectrophotometer.

\section{RESULTS AND DISCUSSION}

SEM is an important analysis for knowing the surface morphology of orange peel powder before and after adsorption at different magnifications. Comparison of SEM images before and after adsorption clearly showed that adsorption took place on the surface of the adsorbent due to the presence of active sites. ${ }^{24,25}$

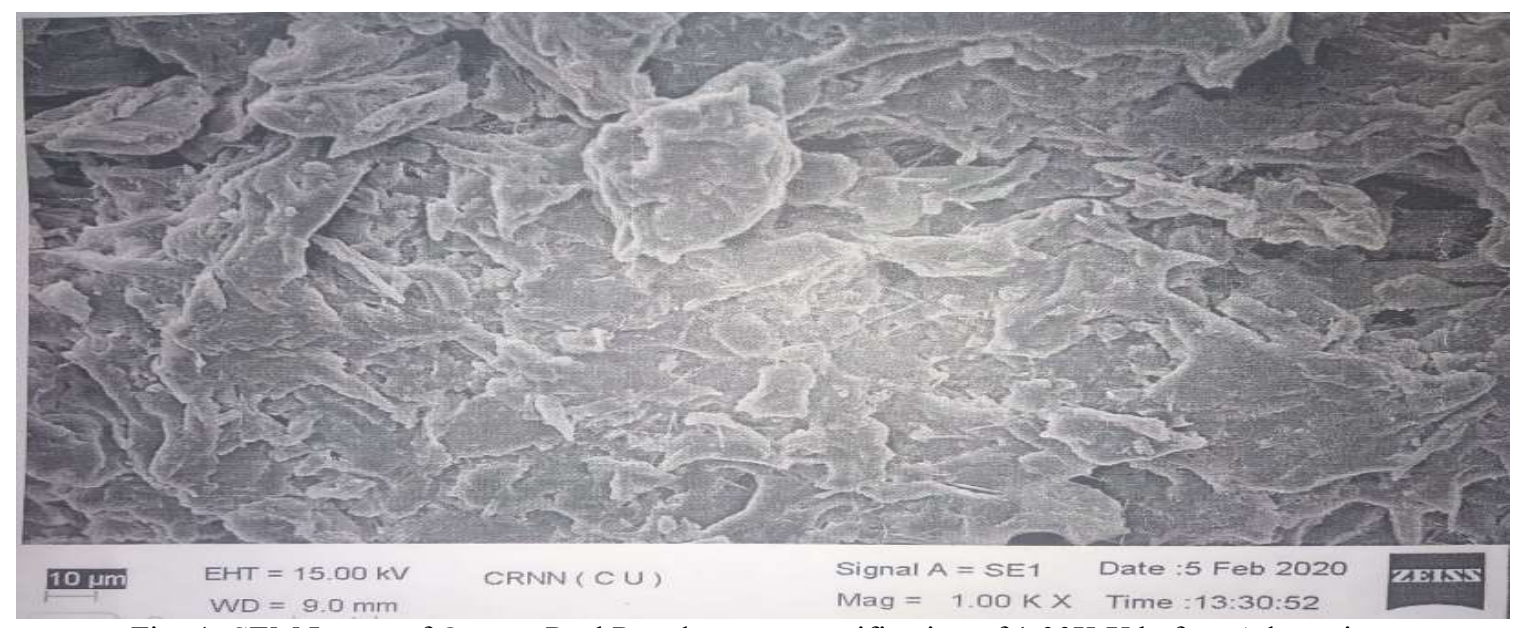

Fig.-1: SEM Image of Orange Peel Powder at a magnification of 1.00K X before Adsorption. 
RASĀYAN J. Chem.

Vol. 14 | No. 2 |1072-1080| April - June | 2021

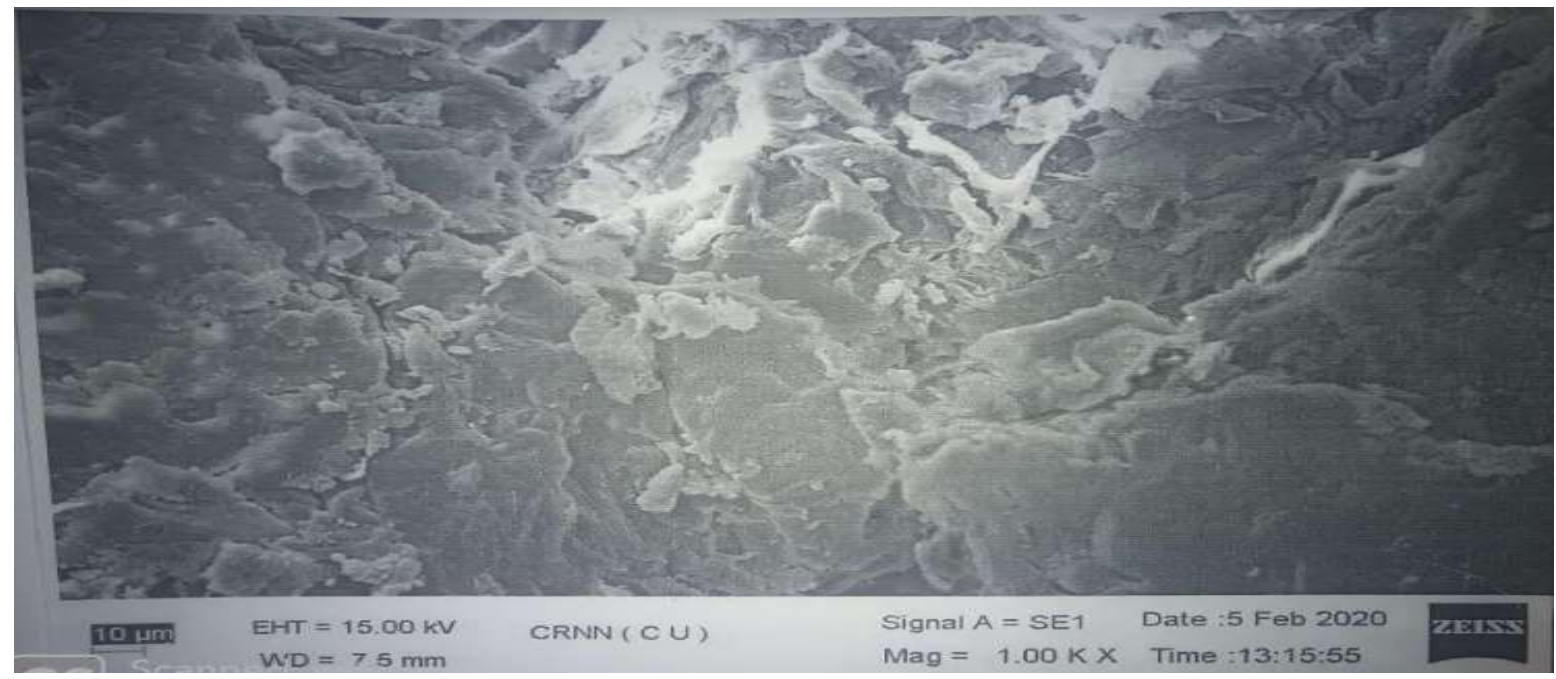

Fig.-2: SEM Image of Orange Peel Powder at a magnification of 1.00K X after Adsorption

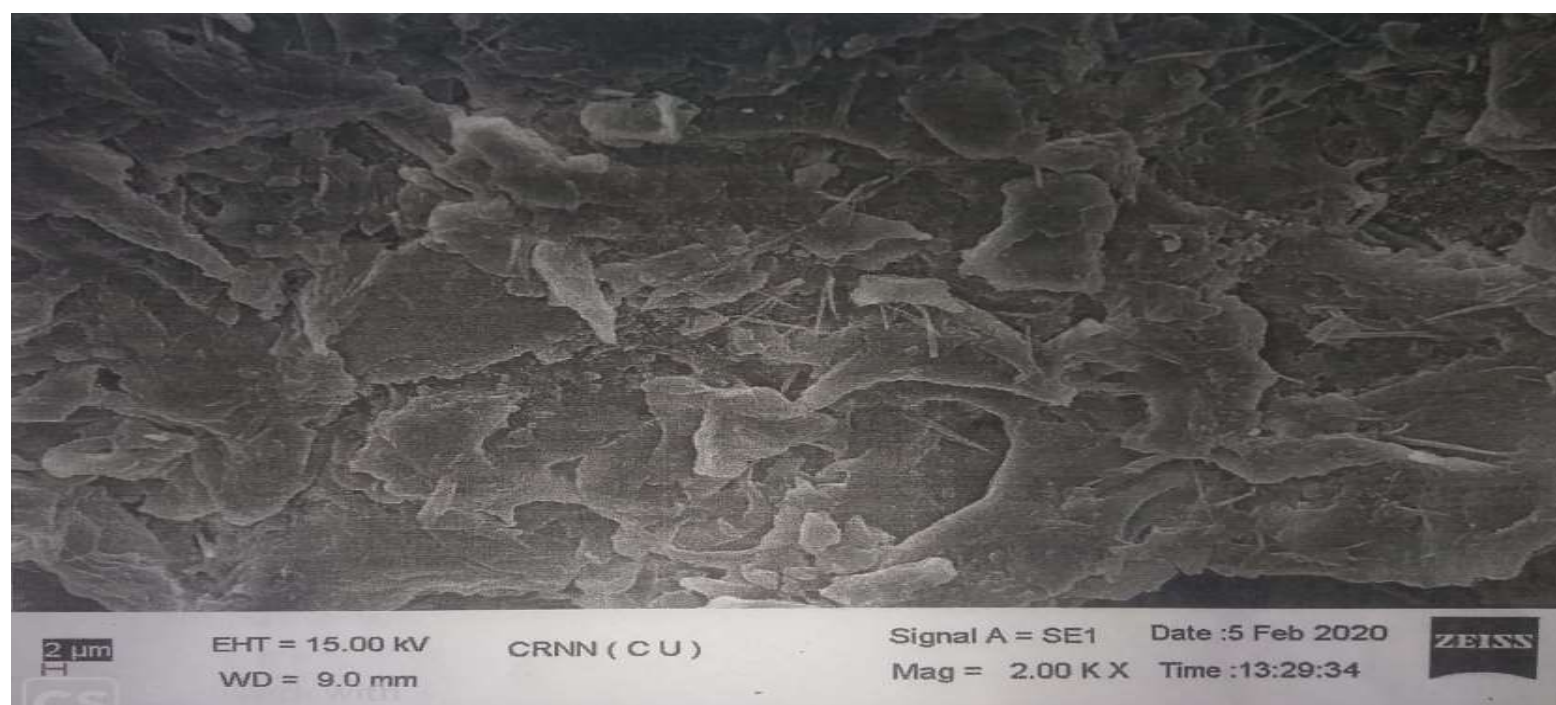

Fig.-3: SEM Image of Orange Peel Powder at a magnification of 2.00K X before Adsorption

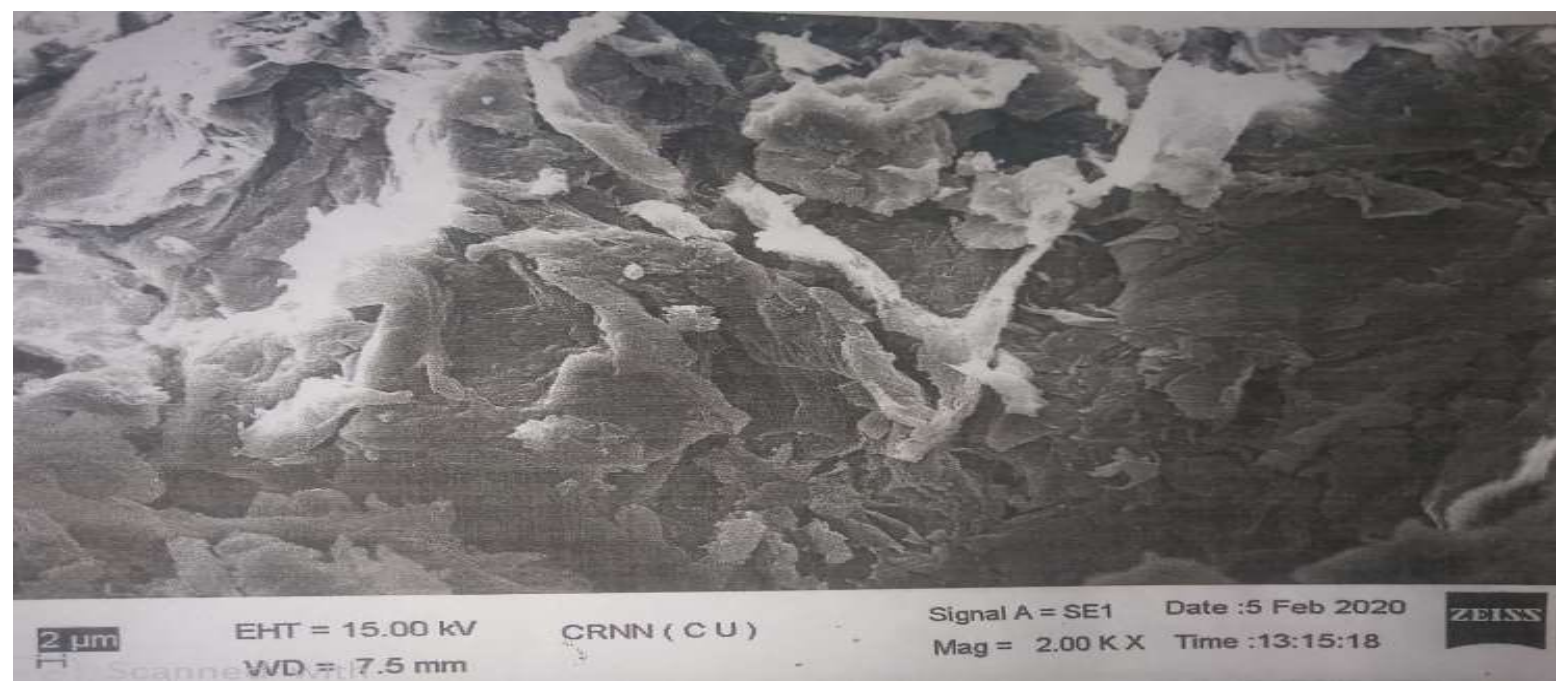

Fig.-4: SEM Image of Orange Peel Powder at a magnification of 2.00K X after Adsorption. 
RASĀYAN J. Chem.

Vol. 14 | No. 2 |1072-1080| April - June | 2021

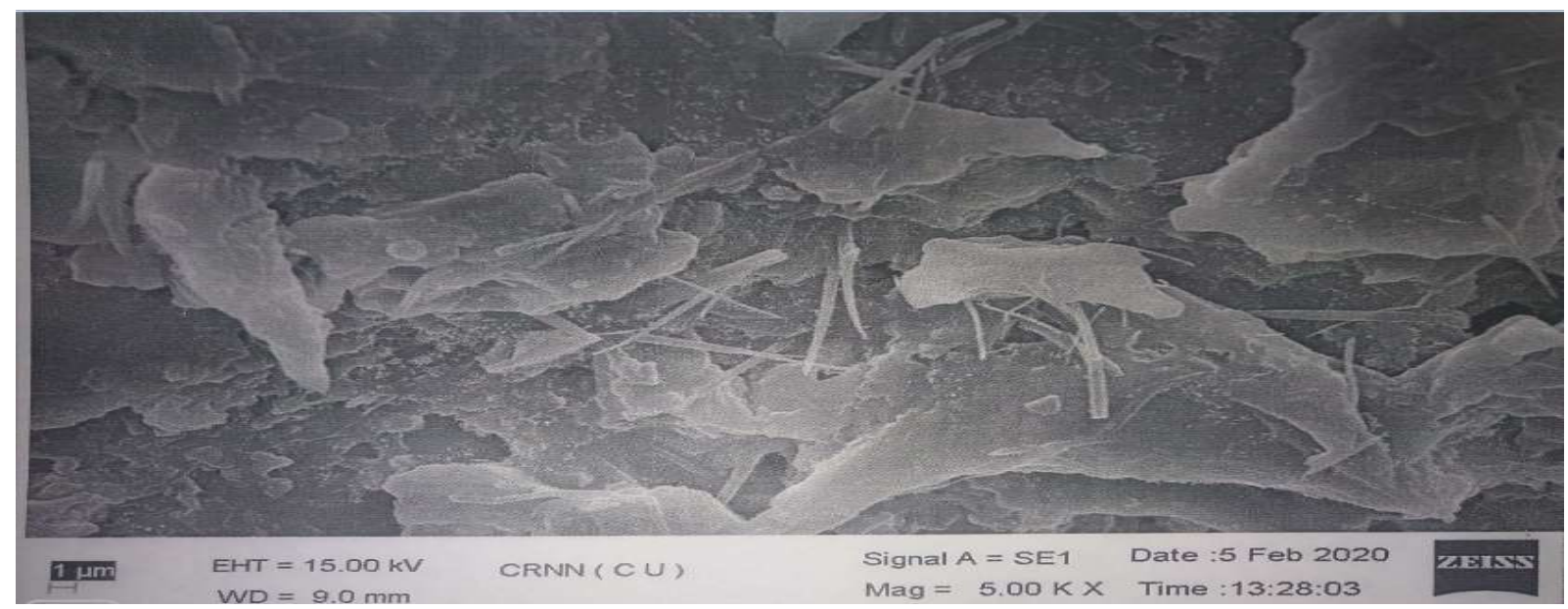

Fig.-5: SEM Image of Orange Peel Powder at a magnification of 5.00K X before Adsorption.

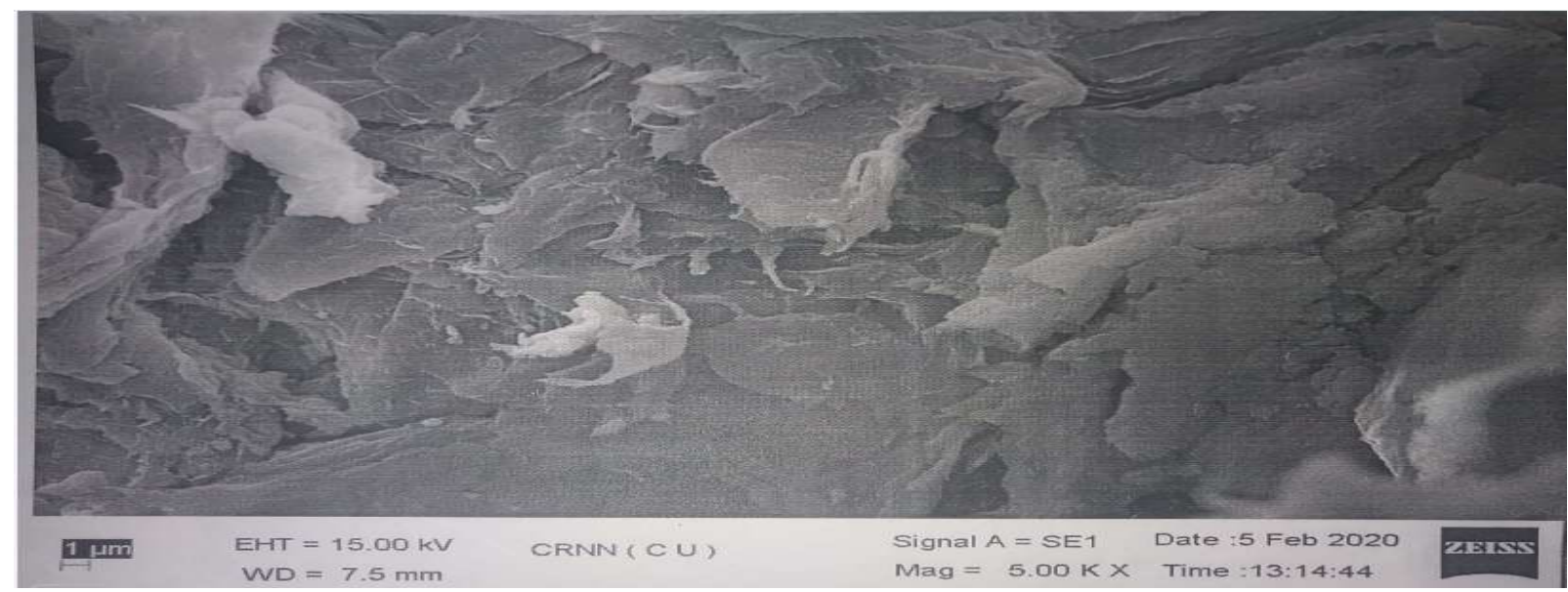

Fig.-6: SEM Image of Orange Peel Powder at a magnification of 5.00K X after Adsorption

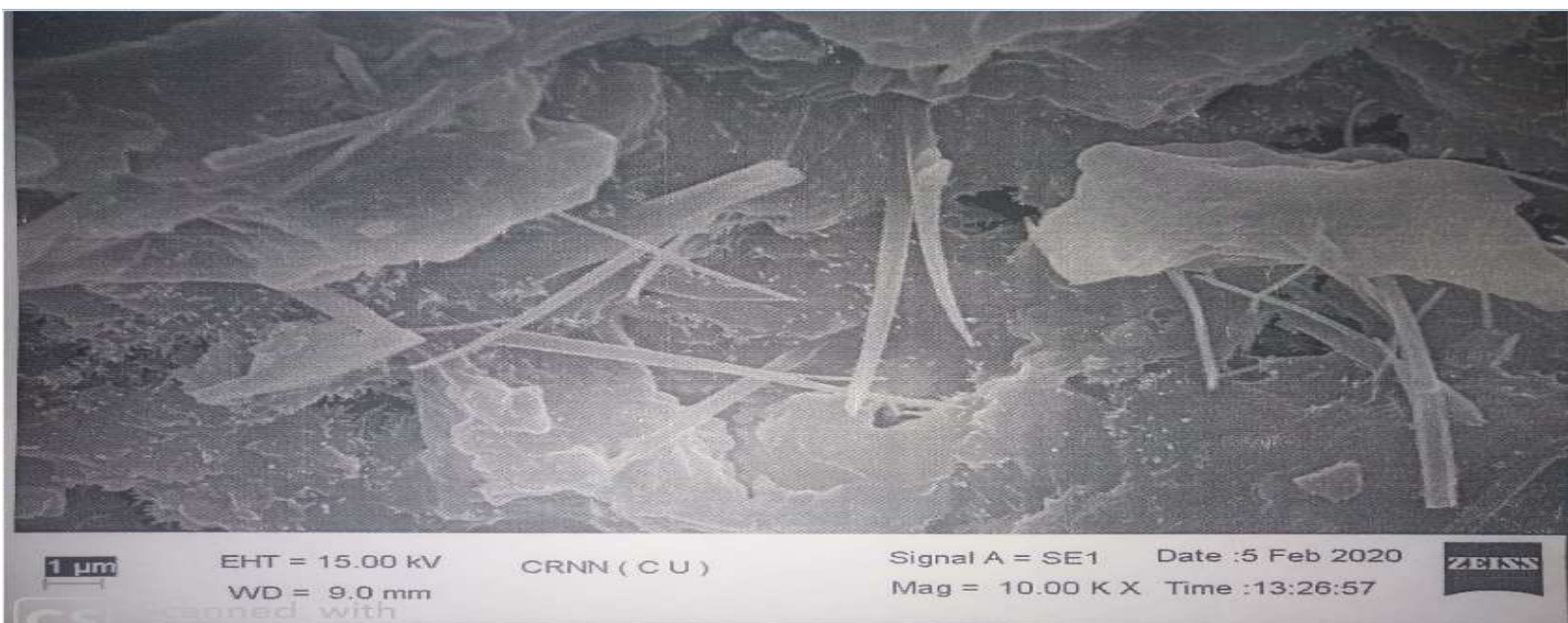

Fig.-7: SEM Image of Orange Peel Powder at a magnification of $10.00 \mathrm{KX}$ before Adsorption.

\section{Effect of Time on Percentage Removal with Orange Peel Powder}

Effect of time on percentage removal shown in Fig.-9and Table-1 describes the residual concentration of As(III) in 10 minutes, 15 minutes, 30 minutes, 60 minutes, 120 minutes, 180 minutes. From table 1 it is clear that an equilibrium concentration of $0.03 \mathrm{ppm}$ is attained in 60 minutes or percentage removal of $98.5 \%$ takes place. 
RASĀYAN J. Chem.

Vol. 14 | No. 2 |1072-1080| April - June | 2021

The percentage removal of As(III) is known by the formula:

Percentage removal $=\left(\mathrm{C}_{\mathrm{i}}-\mathrm{C}_{\mathrm{t}}\right) / \mathrm{C}_{\mathrm{t}} \times 100$.

Where, $C_{i}$ is the initial concentration and $C_{t}$ is the concentration at time t. Fig.- 9: shows a graph of percentage removal versus time with orange peel powder.

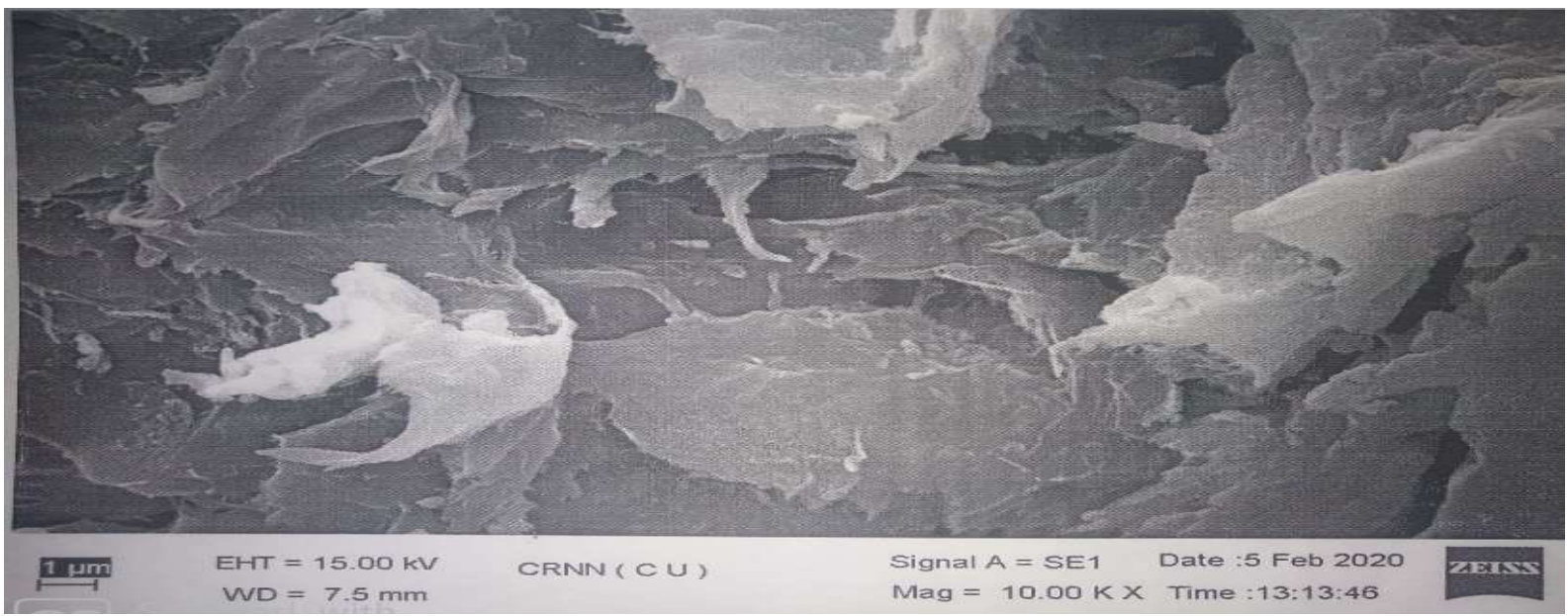

Fig.-8: SEM Image of Orange Peel Powder at a magnification of 10.00K X after Adsorption

Table-1: Residual Concentration of As(III) with Orange Peel Powder at a Different Time Intervalat pH 6.5

\begin{tabular}{c|c|c|c|c|c|c|c|c|c}
\hline S.No. & $\begin{array}{c}\text { Initial } \\
\text { concern- } \\
\text { tration } \\
(\mathrm{ppm})\end{array}$ & $\begin{array}{c}\text { Mass } \\
\text { of Orange } \\
\text { Powder } \\
(\mathrm{gram})\end{array}$ & $\begin{array}{c}\text { Time } \\
(\mathrm{min} .)\end{array}$ & $\begin{array}{c}\text { Residual } \\
\text { Concen- } \\
\text { tration }\end{array}$ & $\begin{array}{c}\% \\
\text { Removal }\end{array}$ & $\mathrm{q}_{\mathrm{t}}$ & $\log \mathrm{q}_{\mathrm{t}}$ & $\log \mathrm{C}_{\mathrm{t}}$ & $\mathrm{C}_{\mathrm{t}} / \mathrm{q}_{\mathrm{t}}$ \\
\hline 1 & $2 \mathrm{ppm}$ & $1 \mathrm{gm}$ & 10 & 0.1 & 95 & 0.19 & -0.72 & -1 & 0.53 \\
\hline 2 & $2 \mathrm{ppm}$ & $1 \mathrm{gm}$ & 15 & 0.06 & 97 & 0.194 & -0.71 & -1.2 & 0.3 \\
\hline 3 & $2 \mathrm{ppm}$ & $1 \mathrm{gm}$ & 30 & 0.05 & 97.5 & 0.195 & -0.7 & -1.3 & 0.2564 \\
\hline 4 & $2 \mathrm{ppm}$ & $1 \mathrm{gm}$ & 60 & 0.03 & 98.5 & 0.197 & -0.7 & -1.5 & 0.15 \\
\hline 5 & $2 \mathrm{ppm}$ & $1 \mathrm{gm}$ & 120 & 0.03 & 98.5 & 0.197 & -0.7 & -1.5 & 0.15 \\
\hline 6 & $2 \mathrm{ppm}$ & $1 \mathrm{gm}$ & 180 & 0.03 & 98.5 & 0.197 & -0.7 & -1.5 & 0.15 \\
\hline
\end{tabular}

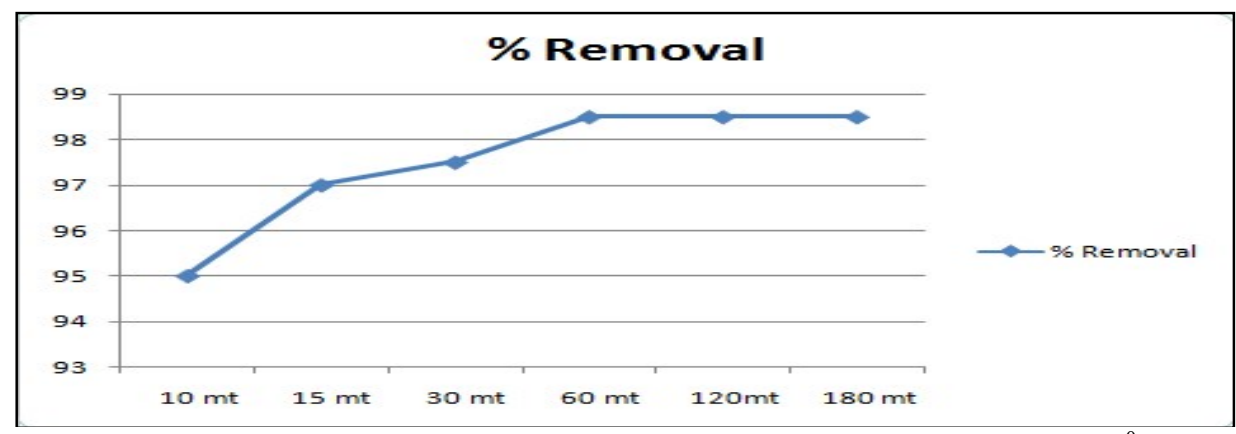

Fig.-9: PercentageRemoval of As (III) Vs Time with $1 \mathrm{gm}$ of Orange Peel Powder at $26^{0} \mathrm{c}$ and $\mathrm{pH} 6.5$

Table-2: Residual Concentration of $100 \mathrm{ml} 2 \mathrm{ppm}$ As(III) Solution after Treatment with Cynodondactylon at $\mathrm{pH} 6.5$

\begin{tabular}{c|c|c|c|c|c|c|c|c|c}
\hline S.No. & $\begin{array}{c}\text { Initial } \\
\text { concentratio } \\
\mathrm{n}\end{array}$ & $\begin{array}{c}\text { Mass of } \\
\text { Cynodon } \\
\text { dactylon }\end{array}$ & $\begin{array}{c}\text { Time } \\
\text { (hour) }\end{array}$ & $\begin{array}{c}\text { Residual } \\
\text { Concen- } \\
\text { tration }\end{array}$ & $\begin{array}{c}\% \\
\text { Removal }\end{array}$ & $\mathrm{q}_{\mathrm{t}}$ & $\log \mathrm{q}_{\mathrm{t}}$ & $\log \mathrm{C}_{\mathrm{t}}$ & $\mathrm{C}_{\mathrm{t}} / \mathrm{q}_{\mathrm{t}}$ \\
\hline 1 & $2 \mathrm{ppm}$ & $10 \mathrm{gm}$ & 24 & $1.3 \mathrm{ppm}$ & 35 & 0.007 & -2.154 & -0.1139 & 185.71 \\
\hline 2 & $2 \mathrm{ppm}$ & $10 \mathrm{gm}$ & 48 & $0.2 \mathrm{ppm}$ & 90 & 0.018 & -1.744 & -0.6989 & 11.11 \\
\hline 3 & $2 \mathrm{ppm}$ & $10 \mathrm{gm}$ & 72 & $0.12 \mathrm{ppm}$ & 94 & 0.0188 & -1.725 & -0.9208 & 6.382 \\
\hline 4 & $2 \mathrm{ppm}$ & $20 \mathrm{gm}$ & 24 & $0.8 \mathrm{ppm}$ & 60 & 0.006 & -2.221 & -0.969 & 133.33 \\
\hline 5 & $2 \mathrm{ppm}$ & $30 \mathrm{gm}$ & 24 & $0.6 \mathrm{ppm}$ & 70 & 0.0046 & -2.337 & -0.2218 & 130.43 \\
\hline
\end{tabular}

REMOVAL OF AS(III) Kiran Kumari et al.

1076 
RASĀYAN J. Chem.

Vol. 14 | No. 2 |1072-1080| April - June | 2021

\section{Adsorption Isotherm}

Freundlich and Langmuir adsorption isotherms have been represented by Figs.-10 and 11 respectively for adsorption of As(III) on orange peel powder. Freundlich Isotherm is obtained by plotting log $\mathrm{q}_{\mathrm{t}}$ versus log $\mathrm{c}_{\mathrm{t}}$ and Langmuir adsorption isotherm is obtained by plotting $\mathrm{c}_{\mathrm{t}} / \mathrm{q}_{\mathrm{t}}$ versus $\mathrm{c}_{\mathrm{t} \cdot}{ }^{26,27} \mathrm{q}_{\mathrm{t}}$ can be expressed as:

$$
\mathrm{q}_{\mathrm{t}}=\left(\mathrm{c}_{\mathrm{i}}-\mathrm{c}_{\mathrm{t}}\right) / \mathrm{m} \mathrm{X} \mathrm{v}
$$

Where,

$\mathrm{C}_{\mathrm{i}}$ is the initial concentration of $\mathrm{As}$ (III) solution

$\mathrm{C}_{\mathrm{t}}$ is the concentration of $\mathrm{As}(\mathrm{III})$ at time $\mathrm{t}$

$\mathrm{m}=$ mass of adsorbent in grams

$\mathrm{v}=$ volume of As(III) solution

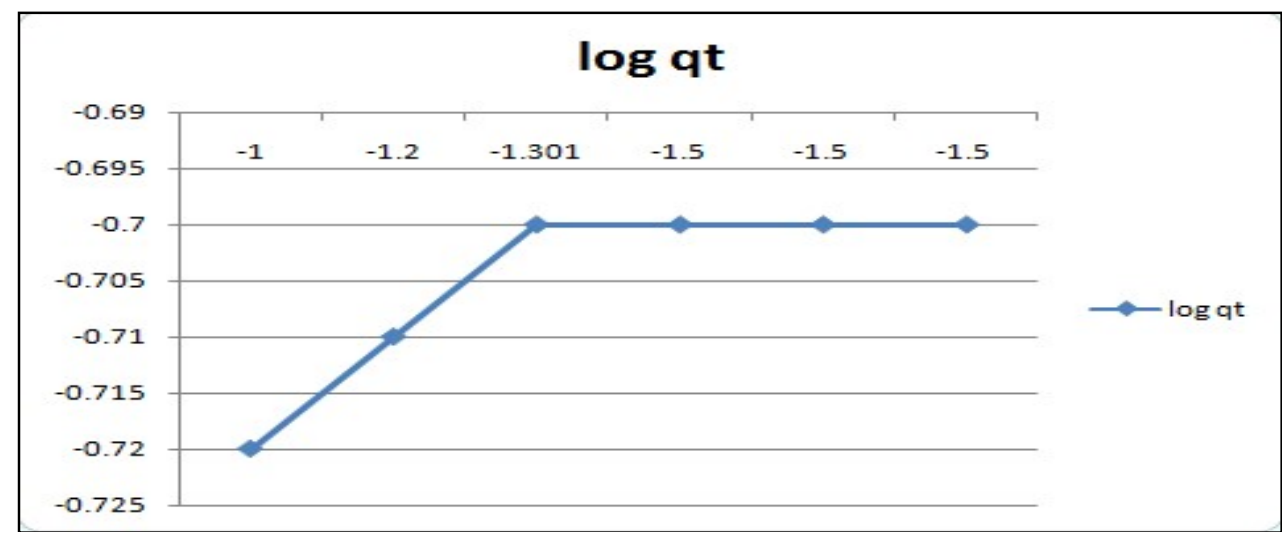

Fig.-10: $\log$ qt Vs log ct (Freundlich Isotherm of As(III)-Orange Peel Powder System) at $26^{\circ} \mathrm{C}$ and $\mathrm{pH} 6.5$

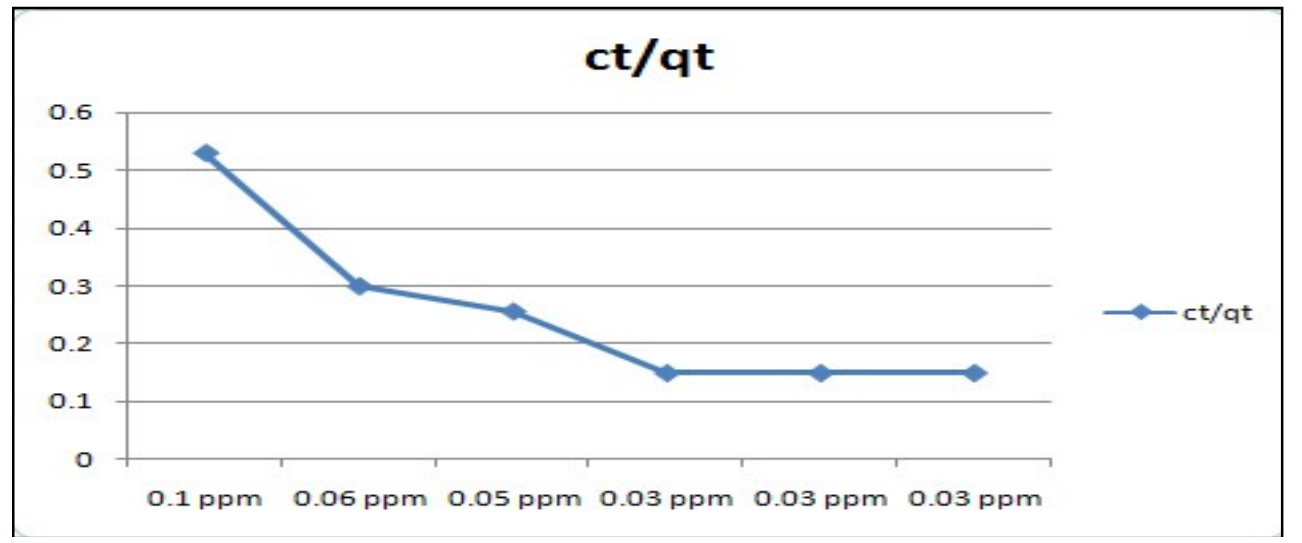

Fig.-11: $\mathrm{C}_{\mathrm{t}} / \mathrm{q}_{\mathrm{t}} \mathrm{Vs} \mathrm{C}_{\mathrm{t}}$ (Langmuir Isotherm of $\mathrm{As}(\mathrm{III})$ - Orange Peel Powder System) at $26^{\circ} \mathrm{C}$ and $\mathrm{pH} 6.5$

Adsorption isotherms have been studied at $\mathrm{pH} 6.5$ for Cynodondactylon at $26^{\circ} \mathrm{C}$ Langmuir and Freundlich isotherms have been explained by Figs.-12 and13 respectively. At pH 6.5 a graph of log $\mathrm{q}_{t}$ versus log $\mathrm{c}_{t}$ has been plotted which shows that Freundlich adsorption is obeyed (Fig.-12).

Figure-11 shows that Langmuir adsorption isotherm is obeyed in case of adsorption of As(III) by orange peel powder. Experimental data explains well Freundlich and Langmuir adsorption isotherms. Experimental data for adsorption of As(III) by Cynodondactylon fit Freundlich and Langmuir adsorption

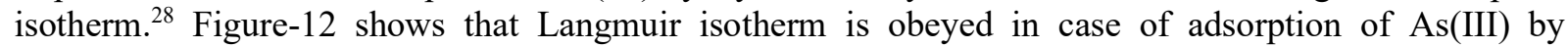
Cynodondactylon and Fig.-13 shows that Freundlich adsorption isotherm is obeyed in case of adsorption of As(III) by Cynodondactylon.

\section{Effect of pH on Adsorption of As(III)}

Cynodondactylon and orange peel powder has been found good adsorbents of As(III) like bentonites. ${ }^{29}$ Effect of $\mathrm{pH}$ has been studied on adsorption as $\mathrm{pH}$ controls the process of adsorption. Here the 
RASĀYAN J. Chem.

Vol. 14 | No. 2 |1072-1080| April - June | 2021

experiments have been done at $\mathrm{pH} 2,4$, and 6.5 with Cynodondactylon and orange peel powder both. At $\mathrm{pH}$ 6.5, the maximum percentage of removal with $10 \mathrm{~g}$ of Cynodondactylon on treatment with $100 \mathrm{ml} 2$ ppm As(III) solution is up to 72 hours is $94 \%$. Removal percentage at $\mathrm{pH} 2$ with similar conditions ranges from $94 \%$ to $98.5 \%$. So maximum percentage removal of As(III) by Cynodondactylon is $98.5 \%$ at $\mathrm{pH} 2$. For $\mathrm{pH}$ varying from 2 to 4 , an increase in percentage removal is not significant. The optimum temperature is $26^{\circ} \mathrm{c}$ and $\mathrm{pH}$ is 2 for maximum adsorption of $\mathrm{As}(\mathrm{III})$ by Cynodondactylon(Fig.-15, Table-4 ) .

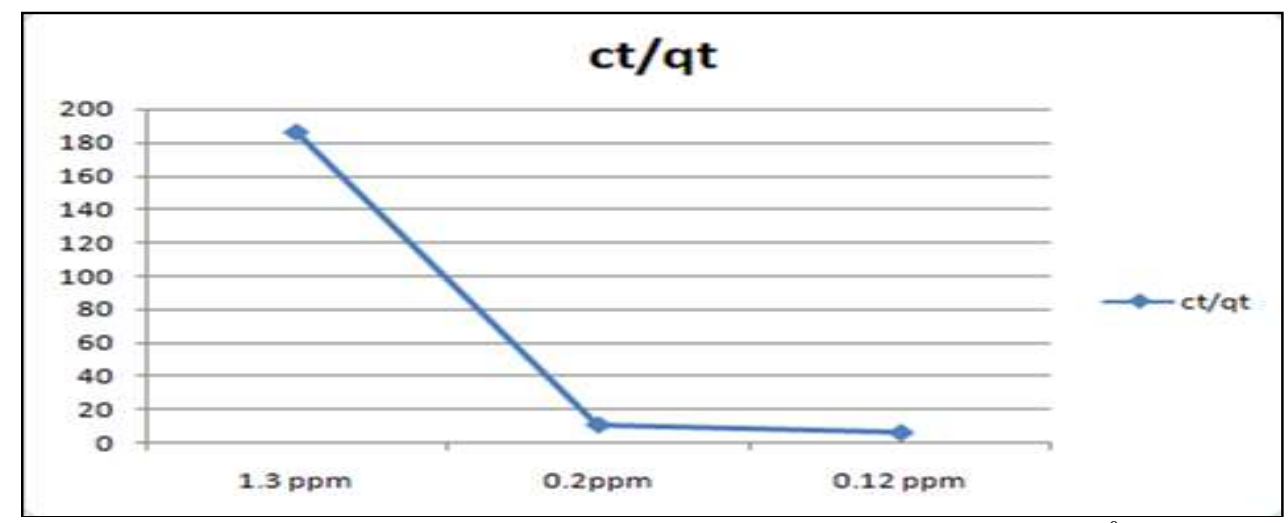

Fig.-12: ct/qt Vs ct (Langmuir isotherm of As (III)CynodondactylonSystem) at $26^{\circ} \mathrm{c}$ and $\mathrm{pH} 6.5$.

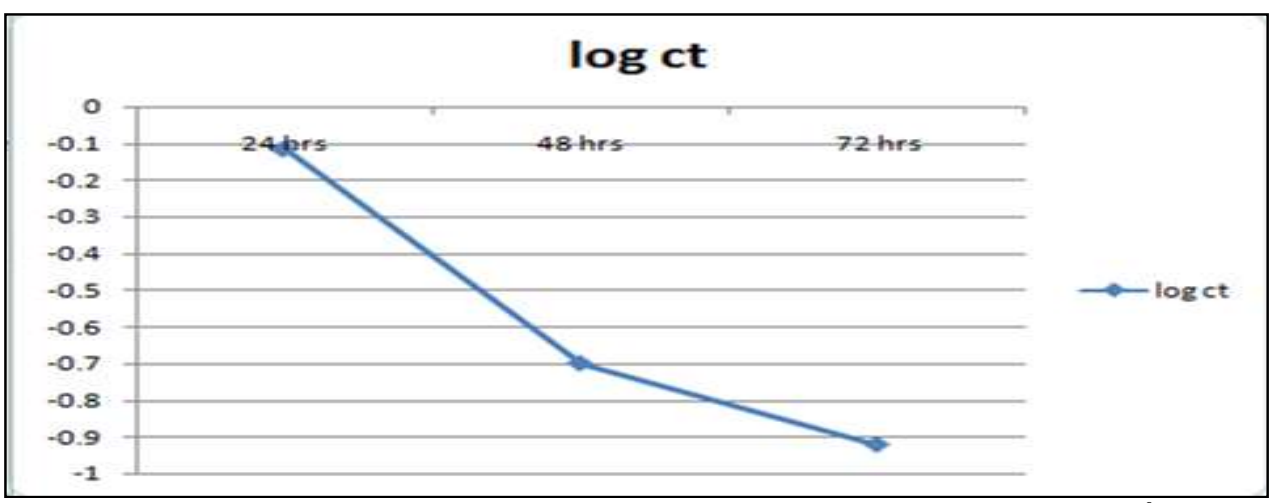

Fig.-13: $\log$ qt Vs $\log$ ct (Freundlich Isotherm of As(III)-Cynodondactylon System) at $26^{\circ} \mathrm{c}$ and $\mathrm{pH} 6.5$

The effect of $\mathrm{pH}$ changes has also been studied for adsorption of As(III) on orange peel powder. Studies have revealed that the maximum percentage of removal at $\mathrm{pH} 6.5$ is $98.5 \%$ and at $\mathrm{pH} 4$ maximum percentage of removal is $99.5 \%$. There is no change in removal percentage on varying the $\mathrm{pH}$ from 4 to 2 . So maximum adsorption takes place at $\mathrm{pH} 4$ or 2(Fig.-14, Table-3). But the effect of $\mathrm{pH}$ change on adsorption of As(III) by orange peel powder does not make any considerable change. ${ }^{30-33}$

\begin{tabular}{c|c|c|c}
\multicolumn{4}{c}{ Table-3: Percentage Removal by Orange Peel at Different $\mathrm{pH}$} \\
\hline Time(minutes) & $\begin{array}{c}\text { Percentage Removal } \\
\text { at } \mathrm{pH} \mathrm{2}\end{array}$ & \%Removal at $\mathrm{pH} \mathrm{4}$ & \%Removal at $\mathrm{pH} 6.5$ \\
\hline 10 & 95 & 98.5 & 95 \\
\hline 15 & 97.5 & 99.0 & 97 \\
\hline 30 & 99.5 & 99.5 & 97.5 \\
\hline 60 & 99.5 & 99.5 & 98.5 \\
\hline 120 & 99.5 & 99.5 & 98.5 \\
\hline
\end{tabular}

Table-4: Percentage Removal by Cyanodon Dactylon at Different $\mathrm{pH}$

\begin{tabular}{c|c|c|c}
\hline Time(Hours) & \% Removal at $\mathrm{pH} 2$ & \% Removal at $\mathrm{pH} 4$ & \% Removal at $\mathrm{pH} 6.5$ \\
\hline 24 & 94 & 90 & 35 \\
\hline 48 & 96 & 92.5 & 90 \\
\hline 72 & 98.5 & 97.5 & 94 \\
\hline
\end{tabular}

REMOVAL OF AS(III) Kiran Kumari et al. 
RASĀYAN J. Chem.

Vol. 14 | No. 2 |1072-1080| April - June | 2021

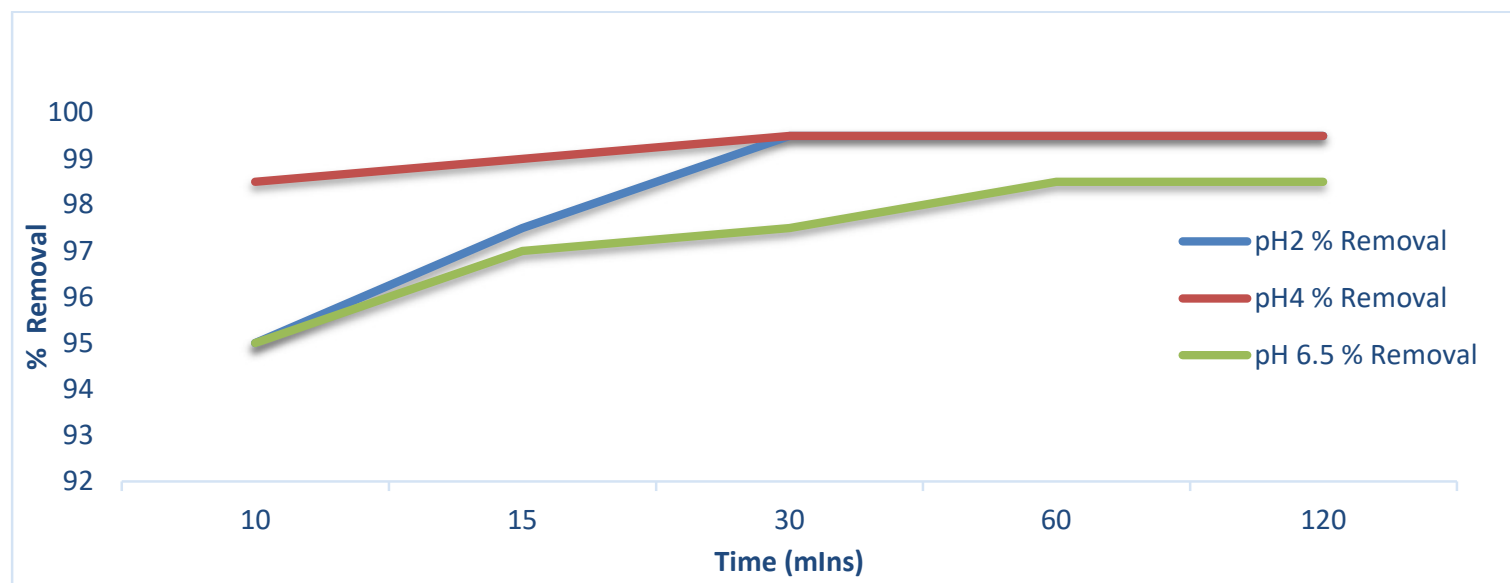

Fig.-14: PercentageRemoval of As(III) by Orange Peel at Different $\mathrm{pH}$

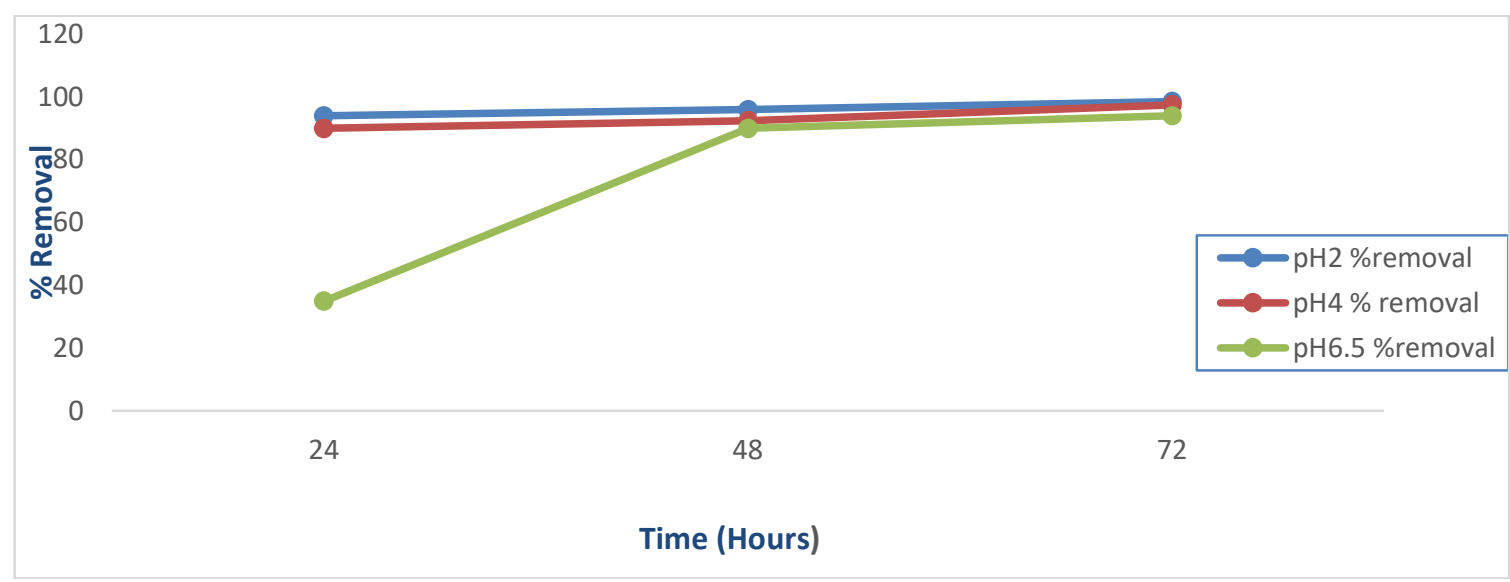

Fig.-15: \% Removal of As(III) by Cynodon Dactylon at Different $\mathrm{pH}$

\section{Effect of Adsorbent Dosage}

The removal of As(III) from aqueous medium increases with an increase in adsorbent dosage. With $10 \mathrm{~g}$ of Cynodondactylon at $\mathrm{pH} 4$ removal percentage is $90 \%$. As the dosage is increased from $10 \mathrm{~g}$ to $20 \mathrm{~g}$, the removal percentage increases from 90 to $94 \%$. When the dosage is further increased to $30 \mathrm{~g}$, percentage removal increases to $96 \%$. This increase in removal percentage may be explained as an increased number of active sites for adsorption due toan increase in adsorbent dose. ${ }^{34}$ But maximum percentage removal is obtained by increasing contact time with a fixed mass of adsorbent.

\section{CONCLUSION}

Potential adsorbents for removal of As(III) from aqueous medium have been utilized and the effect of $\mathrm{pH}$, adsorbent dose, and adsorption isotherms have been studied. The $\mathrm{pH}$ studies revealed that maximum removal of $\mathrm{As}(\mathrm{III})$ by Cynodondactylon and orange peel powder took place at $\mathrm{pH} 2$ to 4 but no considerable variation in percentage removal was marked with variation in $\mathrm{pH}$. An increase in masses of adsorbent increased the percentage removal due to the availability of more active sites on the surface. Isotherm studies clearly showed that Freundlich and Langmuir adsorption isotherms were followed. Cynodondactylon, a perennial weed, and orange peel powder both could be utilized for arsenic mitigation. This low-cost and eco-friendly adsorbent has been established as a potential remover of As(III) from an aqueous medium.

\section{REFERENCES}

1. A. K. Jha and U. Kumar, Journal of Chemical and Pharmaceutical Research, 6(II), 735(2014)

2. K. Kumari and A. K. Jha, Journal of Pharmacognosy and Phytochemistry, 8(3), 3949(2019).

3. T. Gabiella and R. Cini, Science Total Environment, 327, 41(2004). 
RASĀYAN J. Chem.

Vol. 14 | No. 2 |1072-1080| April - June | 2021

4. D. Ghakraborti, A. Hussam and M. Alauddin, Journal of Environment Science Health Part A, Toxic Hazard Substance Environment Engineering, 38,Xi, (2003),.

5. M. M. Rahman, U. K. Chowdhury, S. C. MukherJee, B. K. Mondal, K. Paul and D. Lodth, Journal of Toxicology, 39, 683(2001).

6. T. R. Chowdhury, G. K. Basu, B. K. Mandal, G. Samanta and U. K. Chowdhury, Nature, 401,545(1999)

7. P. L. Smedley and D. G. Kinniburgh, Application Geochemistry, 17(5), 517(2002).

8. World Health Organization Guidelines for Drinking- Water Quality, Health Criteria and Other Supporting Information (World Health Orgainization, Geneva), (1996).

9. K. Kposutic, L. Furac, L. Sipos and B. Kunst, Sep Technology, 42, 137(2005).

10. Y. Y. Chang, K. S. Kim, J. K. Yang and S. M. Lee, Water Science and Technology, 55, 69(2007).

11. P. Ravenseroft, H. Brammer and K. Richards, Wiley-Blackwell, 588 (2007).

12. D.G. Kinnibugh and P. L. Smedley, British Geological Survey Report, WC/00/19, (2001).

13. A. Chatterjee, D. Das, B. K. Mandal, T. R. Chowdhury, G. Samanta, and D. Chakraborti, Analyst, 120, 643(1995).

14. S.K. Acharyya and B.A. Shah, Environmental Geology, 52, 489 (2007).

15. K. Kumari and A.K. Jha, Journal of Emerging Technologies and Innovative Research, 6(2), 450(2019)

16. A. K. Jha and Y. C. Gupta, Chemical Science Review and Letters, 6(24),2120(2017)

17. A. K. Jha and R. K. Dubey, A Modern Approach to Water Pollution, First Edition, Meenakshi Publication, Delhi, 70, (2012).

18. A. K. Jha and U. Kumar, International Journal of Agriculture Environment and Biotechnology, 10(1), 89(2016)

19. U. Kumar, A. K. Jha, R. S. Singh and H. K. Chourasia, (2018), Removal of Arsenic and Chromium From Groundwater by Plant Bio-accumulation: An Overview, Ed.H.K. Chourasia and D.P. Mishra, Today and Tomorrow Printers and Publishers, New Delhi-110002, India, pp.577-592.

20. A. Ansar, L. Punnuswamy, M. Kaur and M. Dutta, Journal of Analytical Sciences, Methods and Instrumentation, 1, 25(2011)

21. O.S. Thirunavukkarasu, T. Viraraghavan, K.S. Subramanian, O. Chaalal, M.R. Islam, Energy Sources, 27, 209 (2005).

22. W. Weeger, D. Lieuremont, M. Perret, F. Lagarde, J.C. Hubert, M. Leroy M.C. Lett, Biometals, 12, 141 (1999).

23. P. Mondal, C.B. Majumdar and B. Mohanty, Journal of Hazardous Materials, 153,136(2008)

24. G, Karthikeyan, Anitha Pius and G. Alagumuthu, Indian Journal of Chemical Technology, 12, 263(2005).

25. S.H. Das, J. Saha, A. Saha, A. K. Rao, B. Chakraborty and S. Dey, Journal of Indian Chemical Society, 96, 447(2019).

26. Mouna Touati Hadjyoussef, Montassar Jendoubi, Mohamad Ben Amor and Memia. Benna-Zayani, Moroccan Journal of Chemistry, 6(1), 135(2018).

27. Anjana Kumari, Ashok Kumar Jha, Pranita, Kiran Kumari, International Journal of Latest Transactions in Engineering and Science, 8(4), 1(2020)

28. P. Rohini Kumar, M. Venkateshwara Rao, N. Chitti Babu, P.V. Ravi Kumar and P. Venkatheshwarlue, Indian Journal of Chemical Technology, 16, 308(2009),

29. A.K. Jha, Chemical Science Review and Letters, 3(12),1182(2014)

30. R. Saxena and S. Sharma, Asian Journal of Chemistry, 29(12), 2743(2017),

31. R. Chatterjee and C. Majumder, Journal of Indian Chemical Society,96, 499(2019),

32. D. Das, K. K. Chattopadhyay and S. Mukherjee, Journal of Indian Chemical Society, 96, 455(2019)

33. R. Sudha and K. Srinivasan, Indian Journal of Environment Protection, 35(4), 300 (2015)

34. S. K. Patel, P. Kumar, G. Srinivasan and D. Singh , Rasayan Journal of Chemistry, 13(3),1293(2020), DOI: 10.31788/RJC.2020.1335725

[RJC-6178/2020] 